by Kottapalli S. Murty ${ }^{l}$ and David Oldroyd ${ }^{2}$

\title{
The 22nd International Geological Congress, New Delhi, 1964
}

\author{
${ }^{1} 101$ Sneh Chaya Apartments, 28 Hindustani Colony, Amaravti Road, Nagpur 440-010, India. E-mail: murtysk1931@yahoo.co.in \\ ${ }^{2}$ School of History and Philosophy, The University of New South Wales, Sydney, NSW 2052, Australia. E-mail: d.oldroyd@unsw.edu.au
}

The Government of India played host to the 22nd International Geological Congress between 14 and 22 December 1964 in New Delhi, India. This was the first meeting of the IGC on Asian soil and possibly the largest scientific conclave ever to take place in India up to that time. The honour might have come in 1952, as Dr D.N. Wadia extended an invitation to hold a meeting in India at the 18th Congress in London in 1948, but there was already an invitation from France to hold one in Algiers in 1952 and the intended invitation from India did not arrive. An invitation from Mexico saved the situation and at the Mexican IGC, attended by Dr M.S. Krishnan, V. P. Sondhi, and Professor C. Mahadevan (Andhra University, Waltair), the invitation came late after the Council had voted for Denmark; and thus the 21st IGC was held in Copenhagen in 1960. It was in a way a natural fulfilment when ultimately the 22nd IGC was held in New Delhi. The Geological Survey of India, the third oldest and the largest in the world at that time, then had more than a thousand personnel on its staff.

Dr Darashaw Nosherwan Wadia, National Professor of Geology and Geological Adviser to the Government of India's Department of Atomic Energy, and doyen of Indian geology, was elected President of the Congress's policy-making body. Dr B.C. Roy, Director General of the Survey, was appointed Secretary-General. He was also Co-ordinator for the Geological Map of Asia and the Far East, which had been presented to the Copenhagen Congress. He was elected one of the Vice-Presidents of the International Association of Hydrogeologists to represent the Asian Region. A Congress Session in India was appropriate because the Indian Bureau of Mines, Oil and Natural Gas Commission, the Atomic Energy Commission, and the State Geological Departments all provided

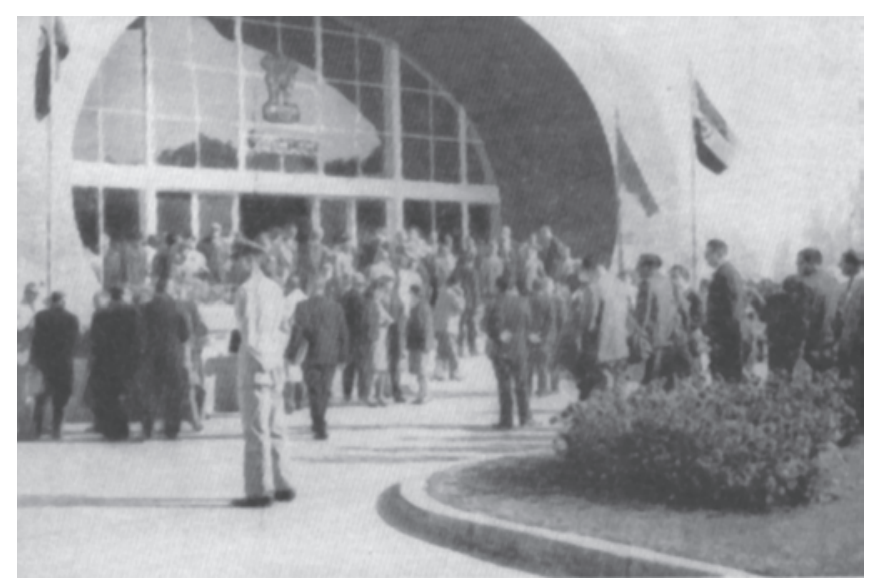

Figure 1. The Congress venue: the Vigyan Bhawan Conference Centre, New Delhi employment to geologists and fifteen universities or other institutions were offering tertiary geological education. India also offered a large variety of problems from the point of view of stratigraphy, tectonics, petrology, and mineral deposits such as iron ore, manganese ore, chromite, base metal ores, gold, coal, petroleum, etc.

The Congress venue was the Vigyan Bhawan Conference Centre in New Delhi (see Fig. 1).

\section{Organization of the Congress}

Sectional Meetings

1 Geology of Petroleum (16)

2 Geological Results of Applied Geophysics (25)

3 Cretaceous-Tertiary Boundary, including volcanic activity (13)

4 Rock Deformation and Tectonics (41)

5 Genetic Problems of Ores (55)

6 Minerals and Genesis of Pegmatites (17)

7 Plateau Basalts (10)

8 Palaeontology and Stratigraphy (37)

9 Gondwana (22)

10 Archaean and Precambrian Geology (38)

11 Himalayan and Alpine Geology (34)

12 Hydrogeology (18)

13 Charnockites (15)

14 Laterite (14)

15 Sedimentary Geology and Sedimentation (24)

16 Other Subjects (36)
Sectional Secretaries

B.G. Deshpande

G. N. Dutt

L.N. Kailasam

A. Roy

M. V. A. Sastry

S.N. Sarkar

I.C. Pande

S. Narayanaswamy

C. Tripathy

D. R. S. Mehta

F. Ahmed

M. R. Subramanyam

A. K. Saha

G. Kohli

V. S. Krishnaswamy

K.S. Valdiya

B. K. Baweja

A.P. Subramanyam

N. Leelananda Rao

M. K. Roy Chowdhury

S. M. Mathur

V. V. Sastri

U. Aswathanarayana
Out of the more than 800 abstracts received, 415, supported by full papers from 380 scientists, were accepted. Papers were received from 43 countries: India (134), USSR (98), France (25), USA (24), Czechoslovakia (16), Canada (11), West Germany (8), Australia (7), Japan (7), Argentina (6), Brazil (6), East Germany (5), Italy (5), Romania (5), United Kingdom (5), Philippines (4), Poland (4), 
South Africa (4), The Netherlands, (3), Formosa (3), Cyprus (2), Libya (2), Norway (2), United Arab Republic (2), Cuba (2), and Mongolia (2). These figures evidently are related to the world's political situation at the time of the Congress.

The sectional meetings started on the forenoon of the 15th and continued up to the afternoon of the 21 st. They were conducted simultaneously in eight rooms. The first two sessions of each section were presided over by eminent scientists from the host country, including Dr D.N. Wadia, Dr W.D. West, Dr M.S. Krishnan, and Professor S.R. Kilpady among others, and subsequent sessions were presided over by eminent visiting scientists, including Dr O.M. Hackett (USA), Dr J.T. Wilson (Canada), Dr G. A. Joplin (Australia) and Dr E. Brotzen (Sweden) and others.

The following countries were represented at the Congress: Afghanistan, Algeria, Argentina, Australia, Austria, Bahrain, Bechuanaland, Belgium, Bulgaria, Burma, Canada, Central African Republic, Ceylon, Colombia, Congo, Cuba, Cyprus, Czechoslovakia, Dahomey, Denmark, Finland, Formosa, France, Gabon, East Germany, West Germany, Ghana, Greece, Haute Volta, Hungary, Iceland, India, Indonesia, Iran, Iraq, Israel, Italy, Ivory Coast, Japan, Kuwait, Liberia, Libya, Luxemburg, Malagasy, Malawi, Malaysia, Mauritania, Mexico, Mongolia, Morocco, Nepal, The Netherlands, New Hebrides, New Zealand, Niger, Nigeria, North Korea, Norway, Pakistan, Philippines, Poland, Romania, Saudi Arabia, Senegal, Somalia, South Africa, Southern Rhodesia, South Vietnam, Spain, Sweden, Switzerland, Tanzania, Thailand, Togo, Trinidad, Tunisia, Turkey, the United Arab Republic, Uganda, the United Kingdom, Uruguay, the United States, the Union of Soviet Socialist Republics, Venezuela, Yugoslavia, and Zambia. (The absence of China may be noted.) There were 646 delegates while the total attendance at the sessions including accompanying members was 1,729 . In all, people from 109 countries were present.

\section{The Opening Ceremony}

The philosopher/statesman and President of India, Dr Sarvepalli Radhakrishnan inaugurated the 22nd IGC in New Delhi on 14 December 1964. His address, which contained some of the best known thoughts from the Upanishads, stressed the need to make use of science and technology, and strive towards spiritual uplift "till the whole mass of humanity is able to mould its emotions into a kind of

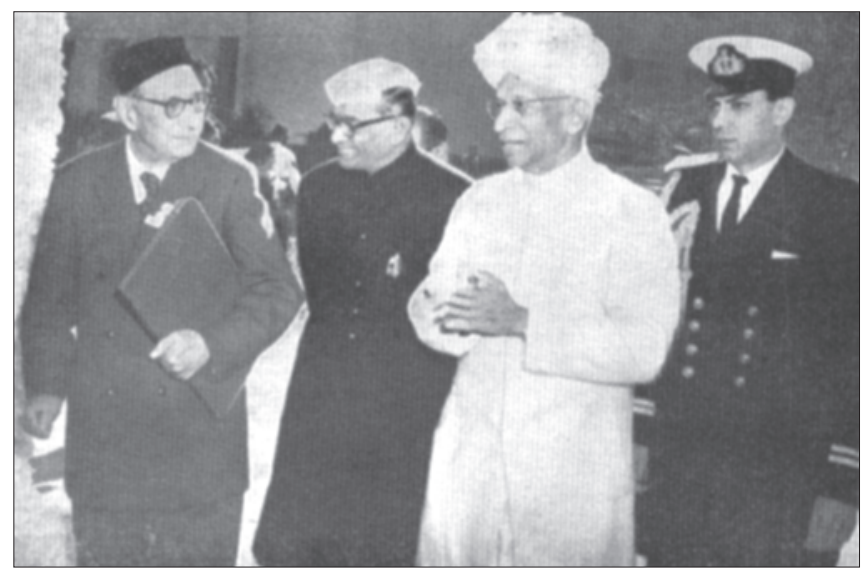

Figure 2. The President of India arriving to address the General Assembly, with the Congress President D.N. Wadia (left), N Sanjiva Reddy, Minister for Steel and Mines, and an unidentified equerry. harmony with the great cosmic purpose; and till the whole mass of humanity becomes an incarnation of the Supreme". The President suggested that the answer to the challenge of the nuclear age, which represented material progress, lay in man's evolution to the final stage beyond the intellect, the stage called Ananda in the holy texts, where man attains freedom of the spirit and looks upon all mankind as of a kindred spirit. He stressed that this was the only way to save mankind from disaster and the new power unleashed by nuclear science for ushering in a paradise on earth. About 1,500 geologists, geophysicists and geochemists from 100 countries listened to this inspiring address; and the President declared the Congress open.

The Congress President, Dr Wadia, then delivered his Presidential Address (see Fig. 3). He gave a brief account of the progress and contributions and achievements of Indian geology. The country's contributions through the Geological Survey of India, one of the oldest national Surveys, were immense in the fields of stratigraphy, palaeontology, and orology - through the exposition of geodetic and gravimetric principles involved in the uplift of the Himalayas and the concomitant depression of the Indo-Gangetic trough. The orogeny,

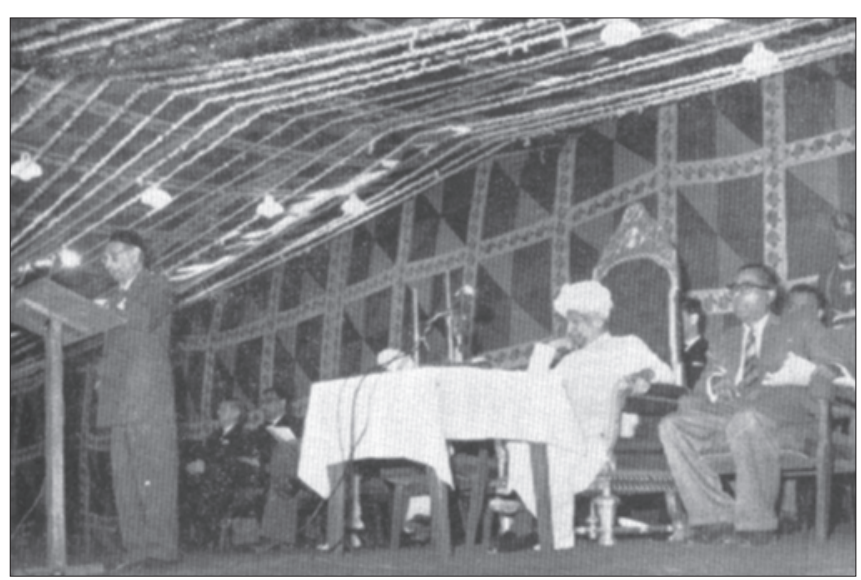

Figure 3. Dr D. N. Wadia addressing the Opening Session of the General Assembly (see also Fig. 4).

no less than the distribution and balancing of other features of the morphology of the Earth's crust, was announced in Calcutta in 1852. This formed a fruitful concept for explaining several anomalies in the dynamics of crustal deformation. The discovery of the Gondwana

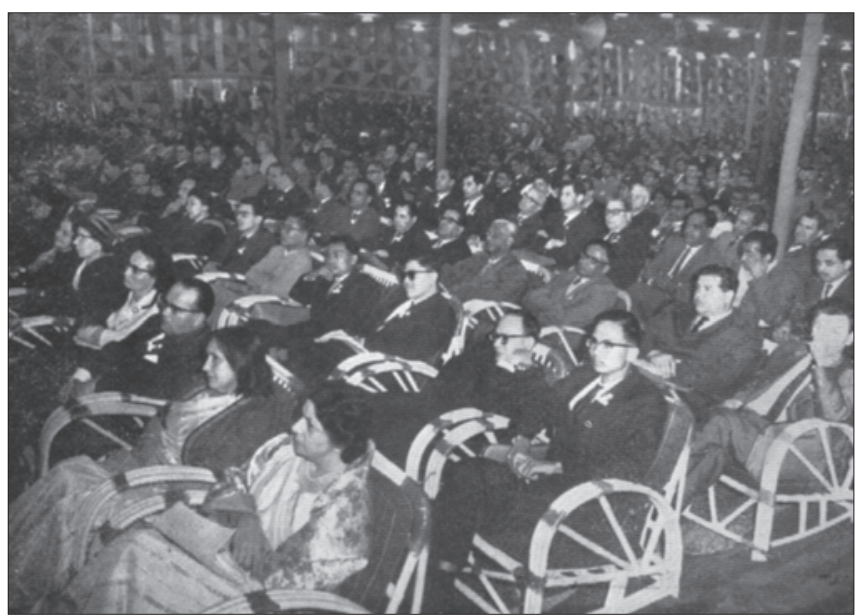

Figure 4. A section of the gathering for the first meeting of the General Assembly. 
System is an epic in the geological history of the Earth and has been a powerful stimulus to geological thought.

\section{Cultural Programme}

As usual at meetings of the IGC, a cultural programme was organised by the host country and also what was in 1964 called a Ladies' Programme, but would today be called an Accompanying Members' Programme. A show of Indian dancers delighted the delegates (see Fig. 5).

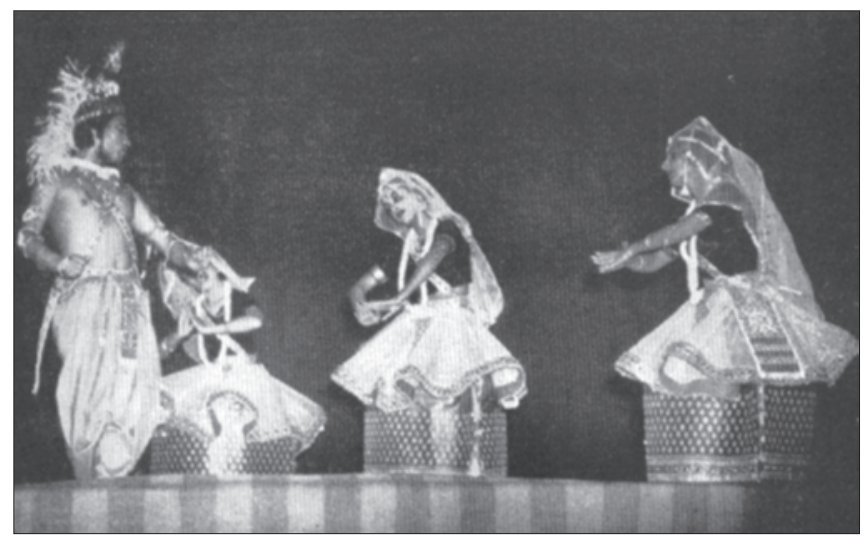

Figure 5. An item from the cultural show.

\section{Congress Exhibitions}

An important aspect of International Geological Congresses is the exhibition of geological maps, publications, instruments, etc., and a suitable exhibition was arranged for the New Delhi meeting. Twentyfive countries took part in the displays, which were a 'shop window' for the world's geologists, where they could display their latest maps, etc. Special mention may be made of the Canadian exhibit under the title 'Canada and the Upper Mantle', the geological map of Czechoslovakia on the scale of 1:200,000, which was prepared according to the most modern methods, and the GDR's instrument display. In all, twenty-two countries displayed their maps (of various types) and some displayed books. India displayed 1:5,000,000 and 1:2,000,000 maps of the whole country, which had taken thirty years to complete. Metallogenic and Mineralogical, and Tectonic, maps on the scale of 1:2,000,000 were also exhibited. There were also special maps of coal regions, gold field areas, copper-bearing and gypsum areas and the western Himalayas (where Dr Wadia had done his most important work in his younger days).

\section{Geological Map of the World}

The preparation of such a map $(1: 1,000,000)$, with standardized stratigraphic subdivisions and colours, was an early preoccupation of the meetings of the IGC in the 19th century, and work had been going on the project ever since, but was still by no means complete in 1962. The responsible Commission was convened in New Delhi and a scheme of work was laid down for the next few years. There was some revision of its membership so that after New Delhi it was:

\section{President}

J. Marcais

Vice-President (North and

W.D. Johnston

Central America)

$\begin{array}{ll}\text { VP (Central America) } & \text { A.R. Lamego } \\ \text { VP (USSR) } & \text { N. Belyaevsky } \\ \text { VP (Africa) } & \text { F. Dixey } \\ \text { VP (Asia and the Far East) } & \text { B.C. Roy } \\ \text { VP (Australia and Oceania) } & \text { J.M. Reyner } \\ \text { VP (Europe) } & \text { H.R. von Gaertner } \\ \text { VP (Middle East) } & \text { M.Mostofi } \\ \text { VP (Antarctica) } & \text { J.R. Adie } \\ \text { Secretary-General } & \text { Ms F. Delany }\end{array}$

It was agreed to reconvene the Commission in Hanover in 1965 and expand its remit to include geochemical, metallogenic, tectonic, and hydrogeological maps, with sub-commissions for each.

\section{The International Indian Ocean Expedition}

The sea floor was recognized as being of economic importance, especially for petroleum, manganese and phosphorus, and the oceans were obviously important for fishing. The Indian Ocean was of special importance as a quarter of the world's population lived around it. Not all the oceanic mineral resources were available for exploitation in the 1960s. Nevertheless it was important to have an inventory of them. Accordingly, an International Indian Ocean Expedition was established by the Special Committee on Oceanic Research of the International Council of Scientific Unions (ICSU), to continue until 1965. The Indian effort was chaired by the indefatigable D.N. Wadia, with N.K. Panikkar as Secretary and Director. Four Indian research ships were involved: Kistna, Varuna, Conch, and Benganda. And some forty vessels worldwide were participating. The studies involved physical oceanography, chemical oceanography, marine biology, meteorology, and marine geology and geophysics. The 22nd Congress provided an opportunity for participants to meet and exchange information and fifteen papers were presented, all directly related to the geological aspects of the programme (e.g. on the physiography of the Indian Ocean, heat flow though the Indian Ocean floor, submarine canyons, gravity surveys, sedimentation in different parts of the Ocean). Such work provided an important part of the developing background to the approaching plate tectonics revolution.

Special group discussions on the results of the 'Expedition' were organized, with the following papers being presented and discussed:
B. C. Heezen and
M. Tharp (USA)
A. S. Laughton and
D. Mathews (UK)
R. P. von Herzen and
M. G. Langseth (France)
A.S. Laughton and
D. Mathews (UK)
H.B. Stewart,
R.S. Dietz and
F. P. Shephard (USA)
D. P. Dash (UK)

G. Evans (UK)

T.C.S. Rao (India)
The physiography of the Indian

Ocean floor

Owen Fracture Zone

Heat flow through the Indian

Ocean floor

Crustal structure profile between

Lamu (Kenya) and the Seychelles

The Ganges and Ceylonese canyons in the Bay of Bengal

Reconnaissance Survey of the Murray Ridge

The Recent sediment facies of the Persian Gulf region

Submarine canyons on the east coast of India 

A. S. Laughton and
D. Matthews (UK)
P. L. Bezrukov (USSR)
Two detailed surveys of the
Carlsberg Ridge
Sedimentation in the central and northern parts of the Indian Ocean
M. Caputo (USA)
E. Seibold (West
Germany)
M. P. Rao (India)
M. J. Lewis and
J. D. Taylor (UK)
A. S. Laughton and
D. Matthews (UK)
Gravity surveys in the Indonesia area and the western Indian Ocean German investigations of the sediments in the Indian Ocean Some aspects of sediments and sedimentation in the Bay of Bengal Marine sediments and bottom communities of the Seychelles Geophysical studies of the sea floor around the Seychelles Island

\section{The Upper Mantle Symposium}

Following the suggestion of V. Beloussov (USSR) an 'Upper Mantle Project' had been initiated by the International Union of Geodesy and Geophysics. The IUGS was interested in the study of the upper mantle and its influence on the development of the Earth's crust. Collaboration between the two Unions began and an Upper Mantle Symposium was held at the New Delhi Congress. Among the several papers presented at the Symposium, Beloussov spoke on the roles that geologists might play (study of continental margins, palaeogeography, deep structures, metamorphic processes, geothermal gradients, the generation of magma). R.J. Uffen (Canada) described the Earth's supposed thermal history and differentiation (into core, mantle and crust) and the processes of magma formation. He suggested also that there was a correlation between geomagnetic reversals and speciation. He suggested that the radius of the core controlled geological and geomagnetic events. M.H.P. Bott (UK) attributed vertical movements of the crust to processes within the mantle, with basins being formed by down-drag as mantle material rose with mountain formation. A similar view was expressed by H. W. Menard (USA), with 'transient phenomena' in the upper mantle causing the elevation and subsidence of ocean floors. Y. Shimazu (Japan) thought of the crust-upper mantle as a kind of heat engine, with inhomogeneities in the crust (e.g. due to sedimentation or volcanism) generating activity in the upper mantle. He had made models to simulate the supposed processes. J. Goguel (France) reviewed ideas on horizontal and vertical movements of the Earth's crust and opined that continental drift was not proven. More work was needed on palaeomagnetism and the topography of the sea floor. M. Gorai (Japan) discussed the development of island arc structures. W. Fahrig (Canada) discussed dyke swarms in the Canadian Shield and thought they indicated a mechanical stretching of continents due to continental drift. Ms E. Plumstead (South Africa) pointed to the significance of fossil plants, which suggested a possible former existence of Gondwanaland. R. M. Deminitskaya (USSR) presented a relief map of the upper mantle and noted its significant features, including the predominance of $\mathrm{N}-\mathrm{S}$ features, and the fact that the mantle of the northern hemisphere appeared to be hotter than that of the southern hemisphere. Earthquake foci in the mantle were apparently associated with two large rings, associated with the Pacific and Atlantic Oceans. All this information belonged to the pre-platetectonic era, but with hindsight one can see that much of it could be related to plate tectonics. It was thought, however, that the evidence was not yet conclusive to suggest whether continental drift did or did

not occur. But further research was advocated to throw light on this question, which was growing in significance at the time of the 22nd Congress. The Upper Mantle Project was subsequently extended (7th and final report, 1972), after a long and extended period of research over a wide range of geological and geophysical investigations. In 1962, deep drilling projects were foreshadowed and some have subsequently been undertaken, especially in the US and Russia, but none have ever reached the Mohorovicic Discontinuity, as was once the aim.

\section{The Closing Assembly}

This was presided over by the Minister for Steel and Mines, Dr N. Sanjiva Reddy (see Fig. 6).

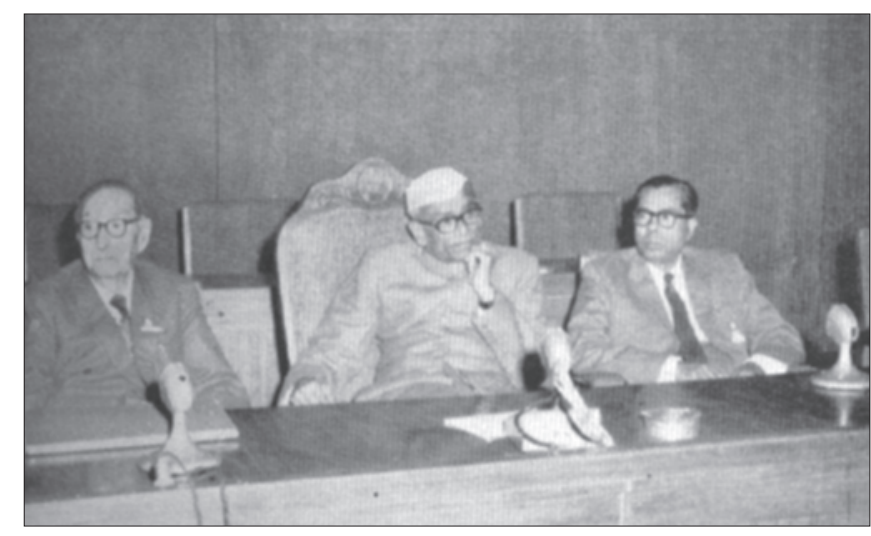

Figure 6. Dr N. Sanjiva Reddy presiding over the closing session of the General Assembly. Left: Dr D.N. Wadia; Right: Dr B.C. Roy (Director, Geological Survey of India).

\section{Field Excursions}

As at other IGCs, field excursions were an important and popular part of the programme. The following were undertaken:

From New Delhi: Simla-Himalaya; Punjab Himalaya and BeasSutlej Project; U.P. Himalaya, Nainital-Almora; U.P. Himalaya, Dehra Dun-Mussoorie-Chakrata; Gwalior-Jhansi-Agra; Udaipur-Jaipur-Ajmer; Jaipur-Ajmer-Udaipur; Kashmir Himalaya

From Nagpur: $\quad$ Nagpur-Pachmarhi-Jabalpur-Katni-Agra; Nagpur-Jabalpur-Katni

From Bombay: Bombay-Aurangabad

From Calcutta: Shillomg Plateau-Kaziranga Sanctuary; Singhbhum and Mayurbhanj; Singhbhum; Sambalpur-Rourkela-Hirakud Dam; Darjeeling and Sikkim Himalaya

From Madras: $\quad$ Mysore-Ooty-Madras; Madras-Mysore-Ooty; Trivandrum-Madras

Excursion guides were prepared in each case and in some instances new maps and sections were specially compiled. It proved very helpful to Indian geology to have its complicated problems examined by a "galaxy of international geologists". About 670 people participated in the excursions. 


\section{Publications}

The following items were distributed to the attending members of the Congress:

D. N. Wadia and W. D. West, Structure of the Himalayas

M. S. Krishnan, Iron-Ores of India

P. Evans and L. P. Mathur, Oil in India

M. R. Sahni, Stratigraphy of the Siwalik Group

U. Aswathanaryana, Determination of ages of Rocks and Geochronology of India

D. R. S. Mehta, Gondwanas of India

P. V. Rao, Geology and Mineral Resources of India

M. V. N. Murthy, Mica Fields in India

List of registrants

Volume of abstracts

Abstract of the group discussion on the results of the International Indian Ocean Expedition

Report of the Sub-Commission on Stratigraphic Terminologydefinition of Systems

History, Function and Organisation of the Geological Survey of India

Geological Map of India, Scale 1:5,000,000

Tectonic Map of India, Scale 1:2,000,000 (to heads of the national delegations only)

Metallogenic Map of India, Scale 1:2,000,000 (to heads of the national delegations only)

Geological Map of India, Scale 1:2,000,000 (to heads of the national delegations only)

\section{Post-Congress Publications}

Proceedings of the Commissions, Sub-Commissions, Committees and Congress Sections and the affiliated international organizations that had held meetings during the Congress along with Congress Proceedings are as follows:

\begin{tabular}{|c|c|}
\hline Part I & General Proceedings \\
\hline Part II & Proceedings of Section 1: Geology of Petroleum \\
\hline Part III & $\begin{array}{l}\text { Proceedings of Section 2: Geological Results of } \\
\text { Applied Geophysics }\end{array}$ \\
\hline Part IV & $\begin{array}{l}\text { Proceedings of Section 3: Cretaceous-Tertiary } \\
\text { Boundary Including Volcanic Activity }\end{array}$ \\
\hline Part V & $\begin{array}{l}\text { Proceedings of Section 4: Rock Deformation and } \\
\text { Tectonics }\end{array}$ \\
\hline Part VI & Proceedings of Section 5: Genetic Problems of Ores \\
\hline Part VII & $\begin{array}{l}\text { Proceedings of Section 6: Minerals and Genesis of } \\
\text { Pegmatites }\end{array}$ \\
\hline Part VIII & Proceedings of Section 7: Plateau Basalts \\
\hline Part IX & $\begin{array}{l}\text { Proceedings of Section 8: Palaeontology and } \\
\text { Stratigraphy }\end{array}$ \\
\hline Part X & Proceedings of Section 9: Gondwanas \\
\hline Part XI & $\begin{array}{l}\text { Proceedings of Section 10: Archaean and Pre- } \\
\text { Cambrian Geology }\end{array}$ \\
\hline Part XII & $\begin{array}{l}\text { Proceedings of Section 11: Himalayan and Alpine } \\
\text { Geology }\end{array}$ \\
\hline Part XIII & Proceedings of Section 12: Hydrogeology \\
\hline Part XIV & Proceedings of Section 13: Charnockites \\
\hline Part XV & Proceedings of Section 14: Laterite \\
\hline Part XVI & $\begin{array}{l}\text { Proceedings of Section 15: Sedimentary Geology } \\
\text { and Sedimentation }\end{array}$ \\
\hline $\operatorname{art} x$ & Proceedings of Section 16: Other Subjects \\
\hline
\end{tabular}

\section{Acknowledgements}

The present paper is based on the more detailed account of the Congress given in: Indian Minerals, Vol. 19. No. 1, XXII International Geological Congress Number, 116 pages, 1965. We thank the Publication and Information Division of the Geological Survey of India for permission to utilise the material from the 1965 publication and for corrections to an earlier version of the present paper suggested by Dr S. Guha. 